\title{
Prolapse and amputation of phallus in a greater rhea (Rhea americana) kept in captivity: Case report
}

\author{
Prolapso e amputação de falo em uma ema (Rhea americana) mantida em cativeiro: Relato de caso \\ Prolapso y amputación del falo en un emú (Rhea americana) mantenido en cautiverio: Reporte de
}

Thais Harumi Kimura

ORCID: https://orcid.org/0000-0002-4245-4735 Universidade Federal do Piauí, Brasil E-mail: harumikimura99@gmail.com

Gabriel Aquino Rocha

ORCID: https://orcid.org/0000-0001-7283-3173 Universidade Federal do Piauí, Brasil E-mail: gabriel.aquinorocha@gmail.com

Hermínio José da Rocha Neto

ORCID: https://orcid.org/0000-0002-5312-5689 Universidade Federal do Piaú, Brasil E-mail: zhermjose@hotmail.com

Miguel Ferreira Cavalcante Filho ORCID: https://orcid.org/0000-0002-7319-9079 Universidade Federal do Piauí, Brasil E-mail: miguelfcavalcante@gmail.com Marcelo Campos Rodrigues ORCID: https://orcid.org/0000-0001-8704-1056 Universidade Federal do Piauí, Brasil E-mail: marcelocampos@ufpi.edu.br

Lilian Silva Catenacci

ORCID: https://orcid.org/0000-0002-2257-7076 Universidade Federal do Piauí, Brasil Universidade Federal do Pará, Brasil Centre for Research and Conservation, Royal Zoological Society of Antwerp, Belgium Saint Louis Zoo Institute for Conservation Medicine, USA

E-mail: catenacci@ufpi.edu.br

\begin{abstract}
Rheas are the largest birds in South America. Belonging to the order of Struthioniformes, they are bred in captivity for their beauty and also for the quality and use of their meat, leather, feathers and eggs. The objective of this report was to describe a case of prolapse and amputation of the phallus after clinical and surgical care of a greater rhea (Rhea americana), to contribute to the literature on the occurrence of this condition in ratites. The animal was raised and is kept in captivity at Federal University of Piauí (UFPI), in Teresina, Piaui state, Brazil. The animal relapsed after two attempts to reduce the phallus prolapse, requiring amputation, since the animal's organ presented areas of necrosis. After the intervention, the animal was returned to the previous enclosure, regrouping with the flock without complications and maintained a normal pre-surgery behavior. To the author's knowledge, this is the first case of phallus and cloaca prolapse reported in Rhea americana.
\end{abstract}

Keywords: Surgery; Prolapse; Ratites; Cloaca; Management.

\section{Resumo}

As emas são as maiores aves da América do Sul. Pertencentes a ordem das Struthioniformes, são muito criadas em cativeiro pela sua beleza, mas também pela qualidade e aproveitamento dos subprodutos, como carne, couro, penas e ovos. O objetivo deste relato foi descrever o prolapso e amputação de falo como resultado de atendimento clínico e cirúrgico de uma ema (Rhea americana americana) pertencente ao plantel do Núcleo de Estudo, Pesquisa e Preservação de Animais Silvestres (NEPPAS) da Universidade Federal do Piauí (UFPI), visando contribuir com a literatura sobre a ocorrência dessa condição em ratitas, mais especificamente em emas. $\mathrm{O}$ animal apresentou recidiva após duas tentativas de redução do prolapso de falo, sendo necessária a amputação, visto que o órgão do animal apresentava áreas de necrose. Depois da intervenção, o animal foi reintroduzido no plantel e não apresentou novas complicações, com inclusive manutenção do comportamento normal antes do procedimento cirúrgico. Até o prezado momento, este é a primeira descrição de prolapso e amputação de falo da espécie Rhea Americana. 
Palavras-chave: Cirurgia; Prolapso; Ratitas; Cloaca; Manejo.

\section{Resumen}

Los ñandúes son las aves más grandes de América del Sur, pertenecen al orden de los Struthioniformes y son criados en cautiverio por su belleza, pero también por la calidad y el aprovechamiento de los subproductos, como la carne, el cuero, las plumas y los huevos. El objetivo de este informe fue describir el prolapso y amputación del falo como consecuencia de la atención clínica y quirúrgica de un emú (Rhea americana americana) perteneciente al personal del Núcleo de Estudio, Investigación y Conservación de Animales Silvestres (NEPPAS) de la Universidad Federal de Piauí (UFPI), con el objetivo de contribuir a la literatura sobre la ocurrencia de esta condición en ratites, más específicamente en ñandúes. El animal recayó tras dos intentos de reducción del prolapso del falo, requiriendo amputación, ya que el órgano del animal presentaba zonas de necrosis. Después de la intervención, el animal fue reintroducido al rebaño y no presentó nuevas complicaciones, incluyendo el mantenimiento del comportamiento normal antes del procedimiento quirúrgico. Hasta la fecha, esta es la primera descripción de un prolapso de falo y amputación de la especie Rhea Americana.

Palabras clave: Cirugía; Prolapso; Ratitas; Cloaca; Manejo.

\section{Introduction}

Most bird species do not have a copulating organ. However, Struthioniformes and Anseriformes have a rudimentary phallus that lies withdrawn inside the male's cloaca. During copulation, the phallus becomes erect due to lymphatic ingurgitation and everts to be inserted in the female cloaca (Origlia et al., 2013; Fehlberg, 2015). Chickens, such as the turkey (Meleagris gallopavo), the cockeral (Gallus gallus) and the jacuassu (Penelope obscura) also have a phallus. However, in these other bird species, only the proctodeus everts to press the phallus again the female's cloaca (Fradson et al., 2011; Marques, 2014).

Phallus prolapse is characterized by continuous exposure of the organ, a condition that might be associated with forced sexual stimulation, such as excessive sexual activity, excessive masturbation or interrupted copulation (Doneley, 2010; Samour, 2015). However, multifactorial causes, such as infectious diseases (Bentubo et al, 2022), avian tuberculosis, duck viral enteritis, traumas, extreme climatic variations, non-specific weakness or emaciation can also lead to prolapse (Doneley, 2010; Samour, 2015).

In cases of prolapse, the recommended approach is to anesthetize the animal, apply a local anesthesia and the return of the phallus to the internal region of the cloaca and a loose suture in the shape of a "tobacco bag" or transversal suture in the site (Tully et al., 2010). This procedure aims to prevent re-exposure of the organ, added to a medical treatment with antiinflammatory and antibiotic medication (Grespan, 2019). In recurrent cases, there is the option of surgical amputation of the bird's phallus, without consequences for the urinary system, once, unlike in mammals, the phalus has no urethra and plays a role only inr reproduction. Studies have reported prolapse associated with infection by Cryptosporidium sp. (Penrith et al., 1994; Santos et al., 2005) and Histomonas meleagridis (Iordanidis et al., 2003) in ostrich chicks raised in captivity. The objective of the present study was to report the first case of phallus and cloaca prolapse in greater rhea and contribute to ratite clinical surgery.

\section{Methodology}

One greater rhea (Rhea americana), male, approximately 2 years old, body mass $31.6 \mathrm{~kg}$, kept in captivity at the Núcleo de Estudos, Produção e Preservação de Animais Silvestres (NEPPAS- (Registro IBAMA nº 02/08-618) at the Federal University of Piauí (UFPI), Brazil was treated.

In July 2020, during the first breeding season of the animal, it showed territorial and disruptive behavior towards other males and a female in the enclosure. And continuous exposure of the sexual organ for more than 24 hours was observed, without spontaneous retraction. 
The animal was manually restrained for a physical examination, which revealed phallus prolapse. The animal was anesthetized with ketamine hydrochloride $(25 \mathrm{mg} / \mathrm{Kg})$ and midazolam $(2 \mathrm{mg} / \mathrm{Kg})$, both via intramuscular (Rocha \& Escobar, 2015). Once the animal was in decubitus, maneuvers were made to replace the phallus in the cloaca reducing the cloacal ostium, in addition to a tobacco bag suture (Samour, 2015). The animal recovered from the anesthesia in 40 minutes and it was regrouped with the other animals. However, after 24 hours, the rhea removed the stitches with its beak, exposing the phallus again. A second attempt was made, with a tobacco bag suture further inside the cloaca. Nevertheless, 72 hours after the intervention, when the suture was removed, the phallus organ prolapsed. Necrosis was observed in the surrounding tissue, with altered coloring, abrasion and loss of function (Figure 1).

Figure 1: An extensive area of necrosis of phallus observed in Rhea Americana.

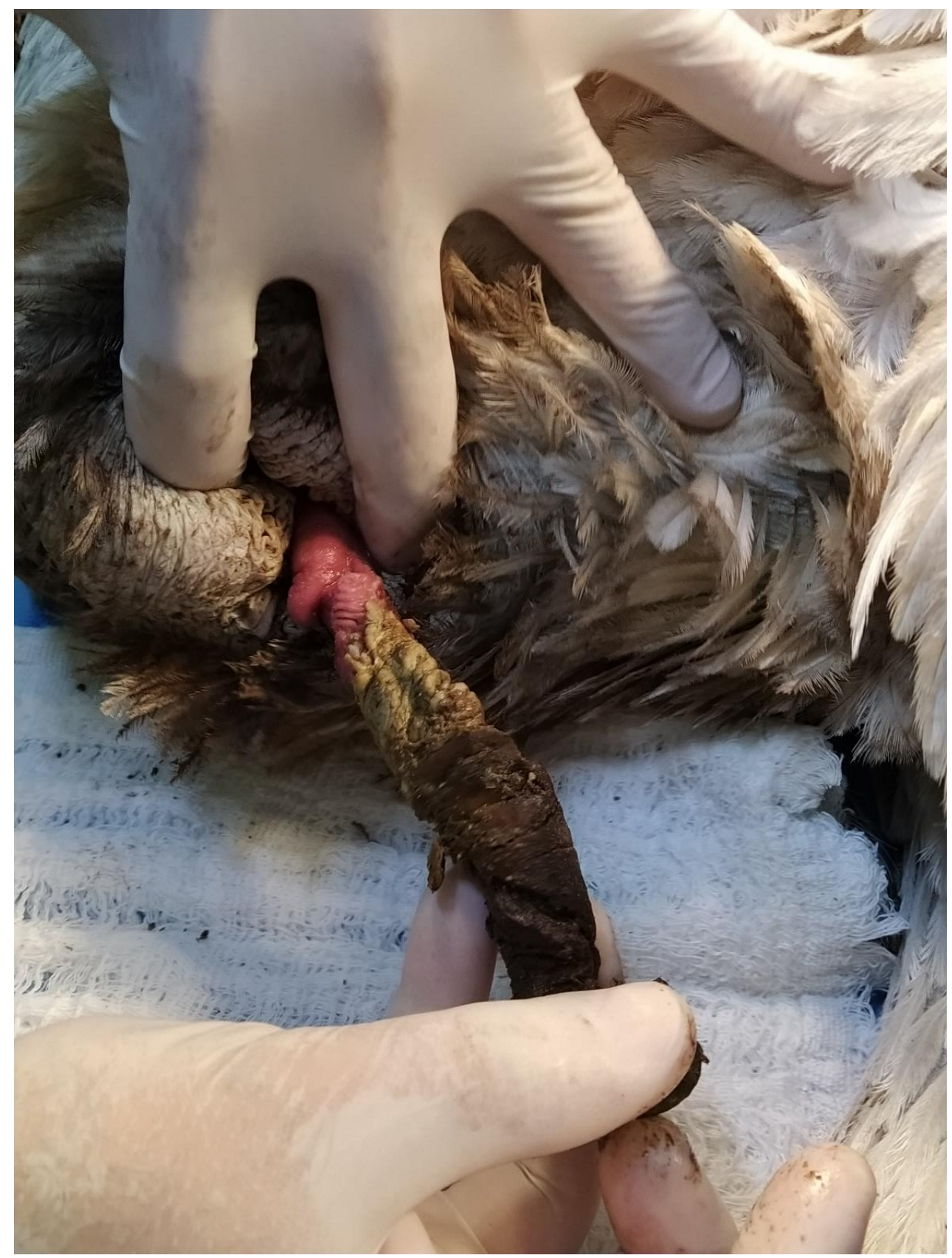

Source: NEPPAS (2021). 
Due to the recurrence of the clinical condition, the animal was sent for surgical intervention with indication for amputation of the phallic organ. As pre-anesthetic medication, ketamine hydrochloride (25mg/Kg) with Midazolam (2mg/Kg), via intramuscular was used. After 5 minutes the animal was prostrated in ventral decubitus and it was transported to the surgery center, where venoclysis of the wing vein was performed for anesthetic induction with Propofol (4 mg/kg).

The animal was intubated with an uncuffed endotracheal tube and kept in isoflurane, under spontaneous open circuit ventilation at $100 \% \mathrm{O} 2$, and heart frequency, respiratory frequency, $\mathrm{O} 2$ and $\mathrm{CO} 2$ saturation and cloacal temperature were monitored constantly. Placed in left lateral decubitus, the feathers were removed, followed by rigorous cleaning of the cloacal region with detergent and antisepsis with chlorhexidine 3\%. After the routine placing of the field cloths, Kelly tweezers were placed transversal to the phallus, below the necrosed region, to excise the organ (Figure 2).

Figure 2: Kelly tweezers positioned transversely to the phallus from Rhea Americana, anterior to the necrotic region which is covered.

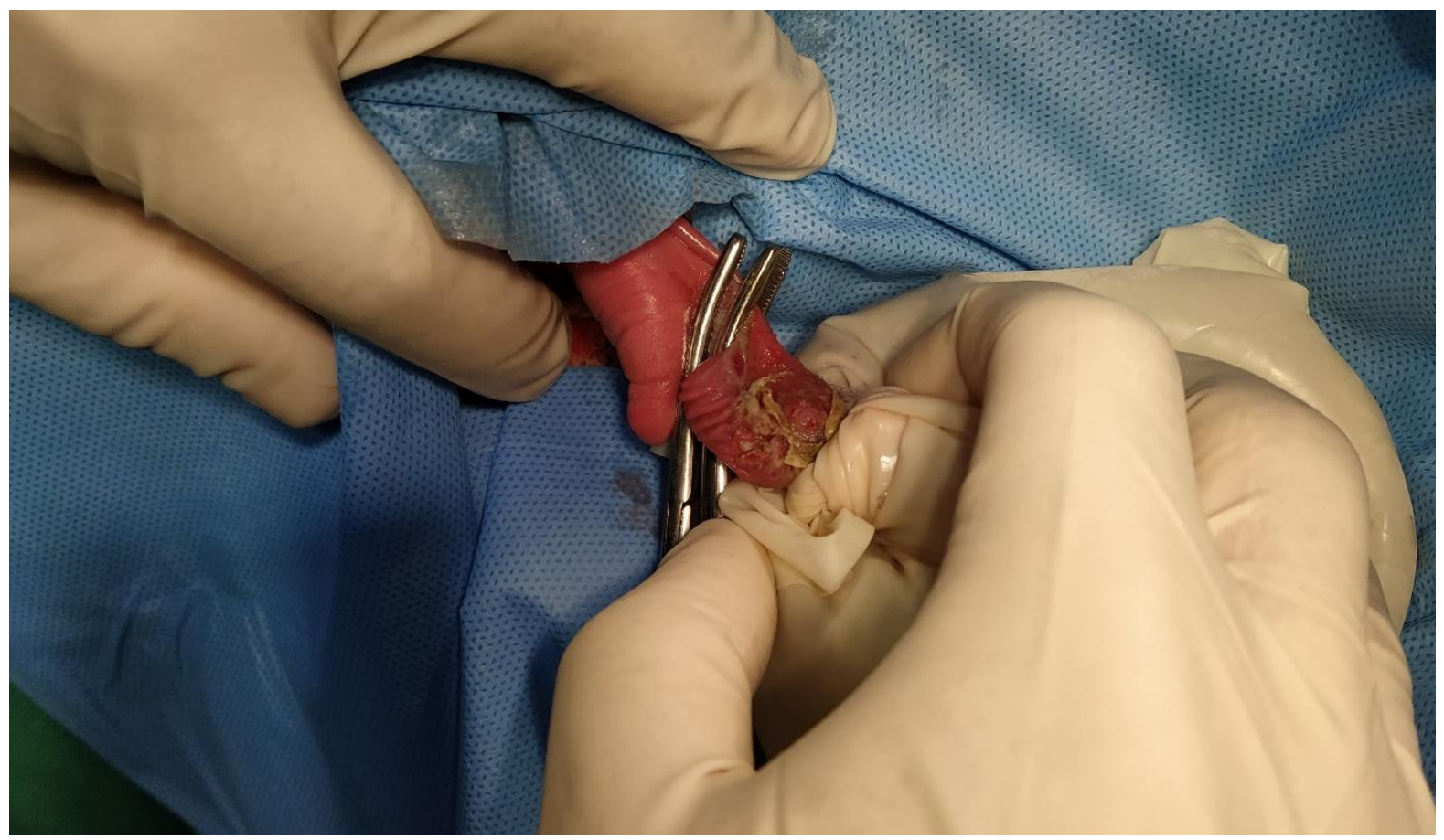

Source: NEPPAS (2021).

The loose phallus conjunctive tissue was sutured with polyglactin 2-0 thread in Sultan pattern. In addition, the mucosa tissue was approximated in simple pattern with polyglactin 2-0 thread (Figure 3) and dermorrhaphy was carried out with absorbable Catgut 2-0 thread in simple separated pattern to prevent later chemical containment to remove the stitches (Figure 4). 
Research, Society and Development, v. 11, n. 3, e41411326015, 2022

(CC BY 4.0) | ISSN 2525-3409 | DOI: http://dx.doi.org/10.33448/rsd-v11i3.26015

Figure 3: The phallus conjunctive tissue sutered with polyglactin 2-0 in Rhea Americana.

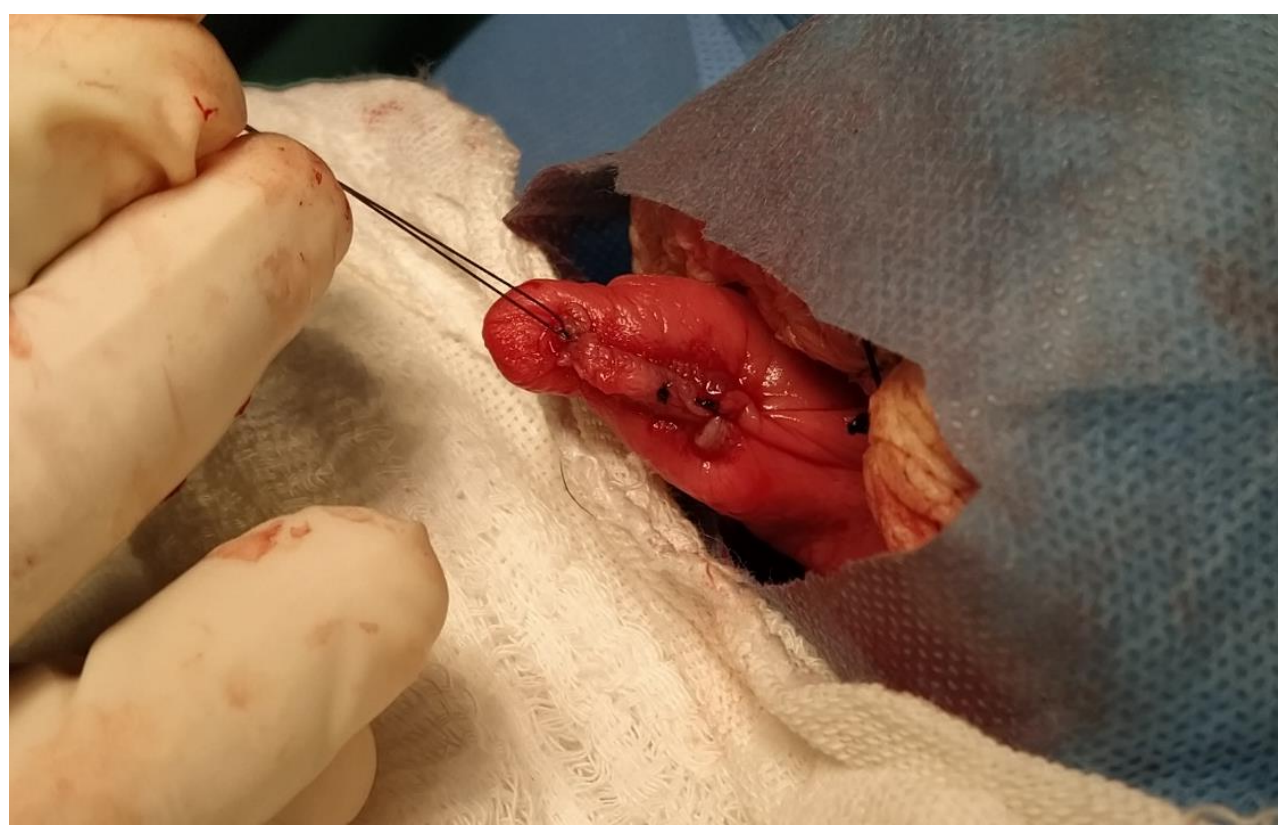

Source: NEPPAS (2021).

Figure 4: Dermorrhaphy method with absorbable Catgut 2-0 thread in simple separated pattern in Rhea Americana.

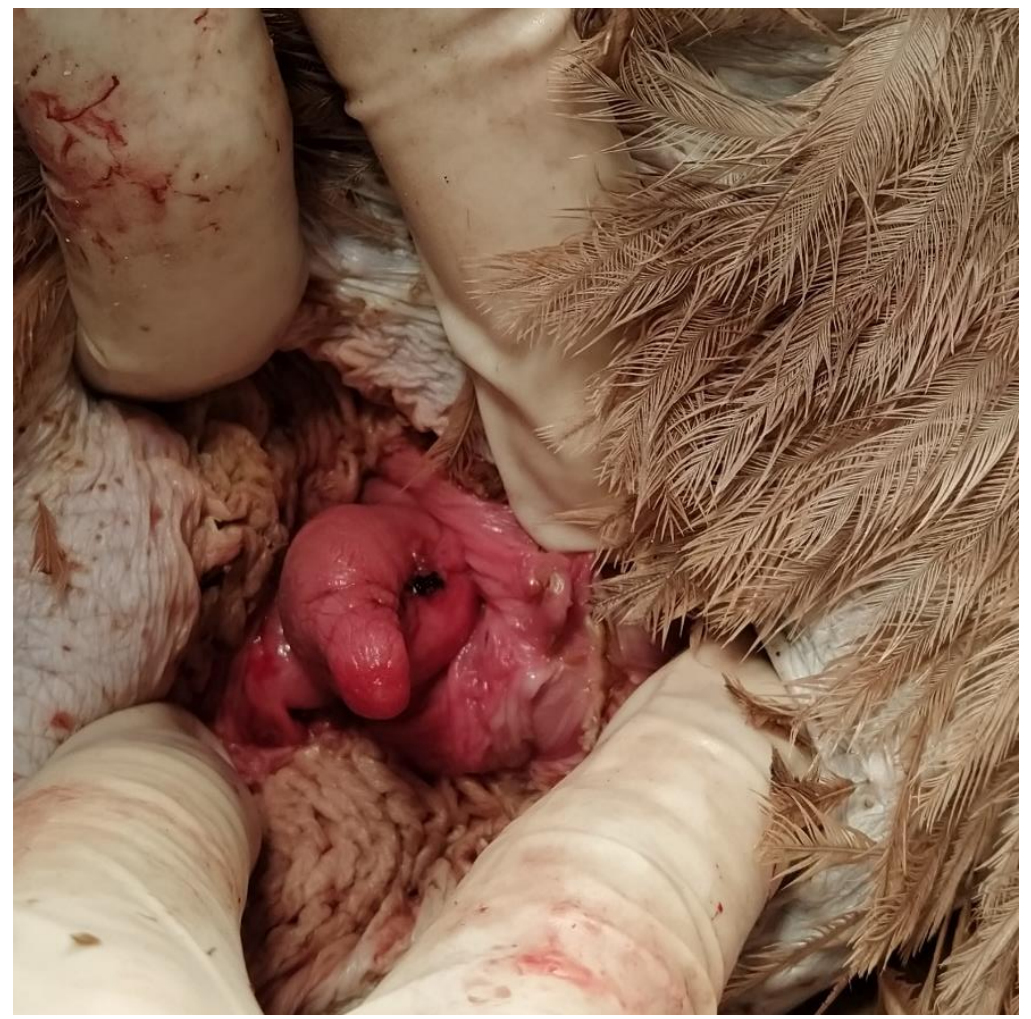

Source: NEPPAS (2021).

The surgery procedure lasted 55 minutes. The mean respiratory frequency was 23 respiratory movements per minute, while the mean heart frequency was 149 beats per minute and the mean cloacal temperature was $38.7^{\circ} \mathrm{C}$.

Right after the surgical procedure, the animal remained in oxygen therapy until the onset of eyelid reflex, swallowing or movement of the neck for deintubation. The animal was moved to an isolated facility for complete anesthetic recovery, during which a long and disturbed recovery was observed, lasting about an hour, with pedaling movements and wing beating, 
and lack of coordination when it tried to stand.

The following medication was administered as post-surgery support treatment: enrofloxacin $(5 \mathrm{mg} / \mathrm{kg}$, via oral) for 5 days (Carpenter \& Marion, 2018): meloxicam ( $0.2 \mathrm{mg} / \mathrm{kg}$, via oral) and Tramadol (2 mg/kg, via oral) for 3 days. All pills were camouflaged in pieces of banana to facilitate the administration of the drugs. After the end of the medications, with full recovery, the animal was reinserted into its group.

In the next reproductive season, twelve months later, the animal maintained the behavior natural to the flock, with equal dispute for the reproducing female.

\section{Results and Discussion}

It is believed that the greater rhea presented phallus prolapse due to dispute for females, with interrupted copulation. Several authors have reported that other ratite species can show the descent of the male genital structure creating phallus prolapse once associated to continuous sexual stimuli, such as excessive masturbation, interrupted copulations, concomitant or not to an inflammatory infectious condition (Gelis, 2005; Doneley, 2010; Tully et al., 2010; Samour, 2015).

In the case of cloaca and phallus prolapse, thorough cleanliness, irrigation, lubrification and structure reduction are recommended (Gelis, 2005; Doneley, 2010), along with systemic antibiotic therapy (Samour et al., 2015), as the procedures carried out in the present report. Considering anesthesia, there are still few studies for rheas and anesthetic protocols for ostrich or other bird species have been the most used (Martins, 2010). As we described in rhea, Swan (1999) observed phallus and cloaca prolapse in an ostrich during a male's first reproductive season. However, the reduction intervention occurred on the same day, that may explain the success of the reduction reported in that study. The phallus amputation procedure does not entail the same complications associated with cloacopexy, such as changes in urination and defecation (Bowles, 2006). This is because the phallus in ratites has only a reproductive function and does not have a urethra in its structure as in mammals (Miller \& Fowler, 2016; Tully et al., 2010).

Gelis (2005), Doneley (2005) and Samour (2015) recommended for prolapse management in ratites, in addition to the total isolation of the animals, reduction in light hours and fewer stimuli to improve recovery. Swan (1999) also suggested separating the male from the rest of the group for six weeks. Unfortunately, there is only one paddock in the facility where the greater rhea was kept, with 8 animals, 5 males and 3 females. So, that made it difficult to separate the patient from the other animals and promote sexual rest after the reduction of the first prolapse occurrence. Lovato (2014) emphasized that the adequate ratio for ratites is one male to every 3 or 4 females and the flock should be divided into groups so that couples can form naturally. Otherwise, the animals should be separated into subgroups, to prevent harmful disputes. This management could not be carried out due to the characteristics of the facility where the greater rhea of the present report lived.

\section{Conclusion}

Disputes among young and adult males in captivity in an imbalanced male-female ratio during the greater rhea reproductive season might have caused the phallus prolapse. Therefore, change is suggested in the reproductive management of the flock with separation into groups. It is believed that the long time of environmental exposure of the phallus, added to the behavior of pecking the corrective suture, without immediate isolation of the animal under treatment, led to the reoccurrences and consequent surgical removal. Management suggestions were passed on to the University to avoid the occurrence of cases with other captive animals.

As the author's knowledge, this is the first case of phallus and cloaca prolapse reported in Rhea americana. 


\section{Acknowledgments}

The authors thank the veterinary team from the Hospital Veterinário Universitário (HVU) "Médico Jeremias Pereira da Silva" da Universidade Federal do Piauí to help with the anesthesia of the animal. We are also grateful to the Veterinary Hospital for providing medical care to the animals kept in captivity at the NEPPAS/UFPI and the keepers Raimundo, Igor and Ricardo for helping with the physical constraint.

\section{References}

Bentubo, H. D. L, Silva, V.F., Mangiaterra, M. B. B. C. D. \& Gonçalves, S.S. (2022). Outbreak due to Fusarium solani on a Brazilian ostrich farm. Research, Society and Development. 11(2), e11411225499, 2022. 10.33448/rsd-v11i2.25499

Bowles, H. L. (2006) Evaluating and treating the reproductive system. In: GJ Harrison, TL Lightfoot (Eds.), Clinical Avian Medicine. 2, 519-539.: Spix Publishing.

Carpenter, J. K. \& Marion, J. C. (2018). Exotic Animal Formulary. Elsevier.

Doneley, B. (2005). Clinical Manegement of Captives Ratites. In: GJ Harrison, TL Lightfoot (Eds.), Clinical Avian Medicine. 2, 957-989. Spix Publishing.

Doneley, B. (2010). Avian Medicine and Surgery in Practice: Companion and aviary birds. 317-331 Manson Publishing Ltd.

Fehlberg, B. H. B. (2015). Morfologia da cloaca e do aparelho copulador de Cairina Moschata (Anatidae: Anseriformes) com implicações sistemáticas [Tese doutorado, Universidade Federal de Minas Gerais, Instituto de Ciências Biológicas]. https://repositorio.ufmg.br/handle/1843/BUBD-ABCEN7

Fradson, R. D., Wilke, W. L. \& Fails, A. D. (2011). Anatomia e Fisiologia dos Animais de Fazenda. (7th ed.), 413. Guanabara Koogan.

Grespan, A. (2019). Aves: prolapso de cloaca. https://www.wildvet.com.br/single-post/2019/03/22/prolapso-de-cloaca

Miller, R. E. \& Fowler, E. R. (2014). Fowler's Zoo and Wild Animal Medicine. 8, 75-82. Elsevier Health Sciences.

Gelis, S. (2005). Evaluating and Treating the Gastrointestinal System In: Clinical Avian Medicine. 1, 411-440. Spix Publishing.

Iordanidis, P. I., Papazahariadou, M. G., Georgiades, G. K., Papaioannou, N. G., \& Frydas, S. E. (2003). Cloacal prolapse in ostrich chicks with histomoniosis. The Veterinary record, 153(14), 434-435. https://doi.org/10.1136/vr.153.14.434

Lovato, M. \& Santos, E. O. (2014). Rheiformes (Emas) e Struthioformes (Avestruzes, Emu e Casuar). In Cubas, Z. S., Silva, J. C. R., \& Catão-Dias, J. L. (Orgs.). Tratado de animais selvagens: medicina veterinária (2th ed.), pp. 310-342). Roca.

Martins, C. X. (2018). Efeito comparativo do uso de cetamina, xilazina, acepromazina e midazolam, em suas combinações, para indução anestésica em emus (Dromaius novaehollandiae) [Tese doutorado, Universidade Estadual do Norte Fluminense Darcy Ribeiro, Centro de Ciências e Tecnologias Agropecuárias]. https://uenf.br/posgraduacao/ciencia-animal/wp-content/uploads/sites/5/2018/09/disserta\%C3\%A7\%C3\%A3o-CAMILLA-XAVIER-MARTINS.pdf

Marques, M. V. R. (2014). Galliformes (Aracuâ, Jacu, Jacutinga, Mutum e Uru). In Cubas, Z. S., Silva, J. C. R., \& Catão-Dias, J. L. (Orgs.). Tratado de animais selvagens: medicina veterinária (2 ed.), 401-437.: Roca.

Origlia, J., Mouly, J. \& Gorriti, G. (2013). Clinica médica y quirúrgica en especies no convencionales resolucion quirurgica de prolapso de falo en un pato. http://www.cvpba.org/assets/files/8\%C2\%BA\%20Jornadas\%20Internacionales\%20de\%20Veterinaria\%20Pr\%C3\%A1ctica\%202013/RESOLUCION\%20QUI RURGICA\%20DE\%20PROLAPSO\%20DE\%20FALO\%20EN\%20UN\%20PATO..pdf.

Penrith, M. L., Bezuidenhout, A. J., Burger, W. P., \& Putterill, J. F. (1994). Evidence for cryptosporidial infection as a cause of prolapse of the phallus and cloaca in ostrich chicks (Struthio camelus). The Onderstepoort journal of veterinary research, 61(4), 283-289.

Rocha, R. W. \& Escobar. A. (2015). Anestesia em aves. Revista Investigação Medicina Veterinária, 14(2), 1-9.

Samour, J. (2015). Avian Medicine. (3th ed.), 49-72. Elservier.

Santos, M. M. A. B., Peiró, J. R. \& Meireles, M. V. (2005). Cryptosporidium infection in ostriches (Struthio camelus) in Brazil: clinical, morphological and molecular studies. Brazilian Journal of Poultry Science, 7(2), 113-117. https://doi.org/10.1590/S1516-635X2005000200008

Swan, R. A. \& Sicouri, O. (1999). Evidence of sperm storage in the female ostrich. Aust Vet J, 77(10), 649-650. DOI: 10.1111/j.1751-0813.1999.tb13152.x

Tully, T., Dorrestein, G. M. \& Jones, A. (2010). Clínica de Aves. (2th ed.). Elservier. 